\title{
KEPUASAN, MOTIVASI, KETERLIBATAN KERJA TERHADAP KOMITMEN ORGANISASI PADA KARYAWAN KAMPUS BANGAU UNIKA MUSI CHARITAS
}

\author{
M.F. SRI SULISTYAWATI \\ sulistyawati@ukmc.ac.id \\ DEWI SRI \\ dewisri@ukmc.ac.id \\ SRI ANDAYANI \\ sriandayani@ukmc.ac.id
}

\begin{abstract}
The purpose of this research is to examine and analyze the Effect of Job Satisfaction, Motivation, Work Involvement on Organizational Commitment in Bangau Campus Employees at Catholic University of Musi Charitas in Palembang. Research respondents were the employees as educators, namely lecturers without additional assignments and lecturers with additional (structural) assignments and employees as educational support staff at the Faculty of Science and Technology and the Faculty of Business and Accounting at Catholic University of Musi Charitas in Palembang. The results of the discussion Against Organizational Commitment In Bangau Campus Employees At Catholic University Musi Charitas of Job Satisfaction, Motivation, Work Involvement. Analysis techniques uses quantitative and qualitative analysis. The research method is a case study. Sampling technique is convinience.. The results of the study are expected to be beneficial to improve job for improving job satisfaction, motivation, involvement and organizational commitment. Furthermore, the results may be beneficial as inputs for various policies needed for the progress and continuity of organizational life. Finally, for further research, this study may be used as the information materials by combining other variables outside the variables that have been studied.
\end{abstract}

Keywords: Job Satisfaction, Motivation, Job Engagement, Organizational Commitment.

\begin{abstract}
ABSTRAKSI
Penelitian yang dilaksanakan mencoba mengkaji dan menganalisis Pengaruh Kepuasan Kerja, Motivasi, Keterlibatan Kerja Terhadap Komitmen Organisasi Pada Karyawan Kampus Bangau Universitas Katolik Musi Charitas Di Palembang. Responden penelitian karyawan sebagai tenaga pendidik yaitu dosen tanpa tugas tambahan dan dosen dengan tugas tambahan (struktural) dan karyawan sebagai tenaga pendukung pendidikan pada Fakultas Sains Dan Teknologi, Fakultas Bisnis dan Akuntansi Universitas Katolik Musi Charitas di Palembang. Hasil Analisis Pembahasan Kepuasan Kerja, Motivasi, Keterlibatan Kerja. Berpengaruh Terhadap Komitmen Organisasi Pada Karyawan Kampus Bangau Universitas Katolik Musi Charitas Di Palembang. Teknik analisis menggunakan analisis kuantitatif dan kualitatif. Metode Penelitian adalah studi kasus.Teknik Pengambilan Sampel adalah convinience. Hasil penelitian diharapkan bisa bermanfaat untuk peningkatan Kepuasan kerja, motivasi, keterlibatan kerja dan komitmen organisasi. Sebagai masukan bagi berbagai kebijakan yang diperlukan guna
\end{abstract}


kemajuan dan kelangsungan kehidupan organisasi. Bagi peneliti selanjutnya penelitian ini sebagai bahan informasi guna penelitian yang akan dilaksanakan di masa mendatang dengan mengkombinasi variabel lain diluar variabel-variabel yang telah diteliti.

Kata Kunci : Kepuasan Kerja, Motivasi, Keterlibatan Kerja, Komitmen Organisasi.

\section{PENDAHULUAN}

Sejarah perkembangan suatu organisasi yang dimulai usaha dari nol dan terus menerus melangkah untuk mencapai kemajuan atau perkembangan, maka dibutuhkan kerja keras. Bagaimana organisasi mencapai kemajuan atau perkembangan maka organisasi harus berupaya memberikan kepuasan kerja bagi karyawannya, sehingga para karyawan berusaha mencapai kemajuan sesuai dengan visi dan misi yang telah ditetapkan oleh organisasi sebagai tujuan untuk perkembangan perusahaan. Karyawan yang mempunyai motivasi kerja dan merasa mempunyai peran atau keterlibatan dalam pekerjaan juga karena merasa mendapatkan kepuasan di dalam pekerjaannya maka karyawan akan mempunyai komitmen di Organisasi tempat kerjanya.

Mondy (2014), menyatakan bahwa Human Resources Management (HRM) is the utilization of individuals to achive organizational objectives. Atau bisa dikatakan Manajemen Sumber Daya Manusia (MSDM) adalah pemanfaatan individu untuk mencapai tujuan organisasi. (dalam buku MSDM, Imam Wahjono,2015:14) Usahausaha mencapai perkembangan dapat dilakukan karyawan jika karyawan merasakan adanya antara lain kepuasan dalam diri, termotivasi, merasa keterlibatan dalam berbagai pekerjaan maka akan mempunyai komitmen. Alasan ketertarikan dengan topik penelitian ini yaitu peneliti pernah melakukan penelitian tentang motivasi karyawan STIE Musi pada tahun 2003. (Dalam buku kumpulan artikel ilmiah lustrum,2003:59,101)

Kemudian pada tahun 2013 tentang pengaruh kepuasan ekstrinsik terhadap kepuasan intrinsik (dalam buku kumpulan penelitian,2014:91). Hasil penelitian tersebut menunjukkan bahwa faktor-faktor kepuasan kerja ekstrinsik yang diberikan belum semuanya memberikan kepuasan kerja intrinsiknya dalam hal gaji, fasilitas, tetapi yang menarik adalah karyawan merasakan hubungan kerja yang baik dan nyaman sehingga hal ini menekan adanya konflik karyawan. Seandainya ada yang mengundurkan diri hal ini hanya kasus-kasus tertentu misalnya mengikuti calon suami, atau kepindahan keluarga. Sedangkan masalah loyalitas masih bisa diandalkan. Saat ini sudah banyak perubahan yang terjadi yang dulunya sekolah tinggi ilmu ekonomi sekarang menjadi Universitas.

Saat ini mengalami perubahan menjadi fakultas bisnis dan akuntansi, dengan penambahan program studi yaitu pendidikan bahasa inggris (PBI) dan pendidikan guru sekolah dasar (PGSD). Perubahan juga terjadi pada sekolah tinggi teknik sekarang menjadi fakultas sains dan teknologi yang terdiri dari: fakultas teknik industri, fakultas teknik arsitektur dan fakultas informatika. Latar belakang inilah yang menjadi alasan peneliti mempunyai keinginan menggali permasalahan yang pernah diteliti pada tahun 2003 dan tahun 2013, guna mengetahui sejauh mana perkembangan motivasi dan kepuasan kerja yang dinikmati karyawan sebagai pendidik (dosen dengan tugas tambahan maupun yang tidak ada tugas tambahan) dan karyawan sebagai tenaga pendukung kependidikan. Tujuan dari penelitian ini untuk mengetahui perubahan yang terjadi pada kondisi kampus bangau yang dulu dan sekarang.

Perbedaan penelitian terdahulu hanya melihat segi kepuasan kerja dan motivasi karyawan saja, sedangkan yang sekarang adalah keinginan mengetahui tidak hanya 
kepuasan kerja, motivasi tetapi juga keterlibatan kerja dan komitmen organisasi, dengan mengikuti segala perubahan yang terjadi didalam organisasi yang semakin berkembang dalam banyak hal baik dari sisi orang atau pelaku kegiatan dan sisi sarana dan prasarana maupun kebijakan-kebijakan yang ada. Alasan tidak mengambil sampel fakultas Ilmu Kesehatan karena berbagai kebijakan pengelolaan maupun fasilitas yang sangat berbeda bahkan masih mengalami penyesuaian perubahan. Jika di kampus bangau selain peneliti juga peneliti lainnya pernah meneliti topik yang hampir mempunyai kesamaan ini. Tujuan peneliti ingin mengetahui perubahan yang terjadi dan dampaknya pada komitmen organisasi dengan adanya nilai-nilai champion. Kemudian keterkaitan antara masing-masing variabel bahwa karyawan bila merasakan kepuasan kerja, punya motivasi dan merasa berperan dalam pekerjaannya atau merasa ada keterlibatan yang mendalam dalam pekerjaannya maka akan mempunyai komitmen dalam organisasi. Hal ini juga menjadi ketertarikkan meneliti dengan topik: Pengaruh Kepuasan Kerja, Motivasi, Keterlibatan Kerja Terhadap Komitmen Organisasi Pada Karyawan Kampus Bangau Universitas Katolik Musi Charitas Di Palembang. Berdasarkan uraian tersebut maka dapat dirumuskan: "Bagaimanakah Pengaruh Kepuasan Kerja, Motivasi, Keterlibatan Kerja Terhadap Komitmen Organisasi Pada Karyawan Kampus Bangau Universitas Katolik Musi Charitas Di Palembang.”

\section{TELAAH TEORITIS DAN PENGEMBANGAN HIPOTESIS Kepuasan Kerja}

Kepuasan kerja adalah :'Suatu sikap yang dimilki pekerja mengenai pekerjaan mereka. Hal ini dihasilkan dari persepsi mereka mengenai pekerjaan."(Ivancevich dkk.,2011:186). Kepuasan kerja merupakan salah satu refleksi dari kinerja cipta, rasa dan karsa yang dimiliki oleh individu. Ketika seseorang memiliki suatu kebutuhan (karsa) yang perlu dipenuhi maka ia akan melakukan berbagai upaya dengan mengerahkan pikiran, tenaga, waktu dan kemungkinan harus mengambil resiko yang dapat terjadi dalam melaksanakan pekerjaannya. Kemudian individu tersebut akan berpikir (cipta) untuk mengevaluasi apakah segala upaya nya itu memberikan hasil yang dapat memenuhi kebutuhannya. Apabila hasil dari berpikir menyatakan hasil dari upaya nya telah dapat memenuhi kebutuhannya maka individu tersebut akan merasa (rasa) puas. Sebaliknya maka ia akan tidak puas atau merasa kecewa. (Suparyadi,2017:445) Pengaruh Kepuasan Kerja Terhadap Beberapa Varibel (Suparyadi,2017:446-447) antara lain :

a. Kepuasan kerja dan Motivasi, penelitian menunjukkan bahwa terdapat hubungan yang positif dan signifikan antara motivasi dan kepuasan kerja. Pada umumnya karyawan menyukai pekerjaan yang menantang artinya untuk melaksanakan pekerjaan itu memerlukan upaya tertentu dan mengerahkan kemampuan dan keterampilannya dengan skala yang cukup tinggi jika hasilnya sesuai yang diharapkan maka akan puas dan selanjutnya akan lebih termotivasi untuk berkinerja lebih baik.

b. Keterlibatan dalam pekerjaan, karyawan yang puas akan pekerjaannya dan termotivasi akan lebih menyukai pekerjaannya tersebut. Kesukaan terhadap pekerjaanya direfleksikan pada aktivitas kerja yang intensitasnya makin tinggi, menekuni Pekerjaannya lebih mendalam, dan selalu berusaha mengembangkan kreatifitas dan inovasi dalam melaksanakan pekerjaannya itu.

c. Komitmen Organisasi, hasil suatu penelitian menunjukkan bahwa terdapat hubungan yang signifikan antara kepuasan, motivasi, keterlibatan dengan 
komitmen organisasi, yaitu bahwa karyawan yang puas, termotivasi, berperan serta dalam berbagai pekerjaan, maka akan memiliki komitmen yang tinggi terhadap organisasi. Karyawan yang puas, termotivasi dan berperan dalam berbagai pekerjaan, maka akan cenderung memiliki komitmen, dapat dikatakan mempunyai kemauan yang kuat untuk memberikan kontribusi dalam upaya mencapai tujuan. Karyawan ini juga tidak akan meninggalkan organisasi walaupun mungkin mendapatkan tawaran kompensasi yang lebih baik dari pada yang mereka terima dari organisasinya saat ini. Tabel 1 menunjukkan kekuatan hubungan antara berbagai variabel dari hasil penelitian.

Tabel 1

Hubungan Kepuasan Dan Variabel Lain

\begin{tabular}{llcc}
\hline No. & \multicolumn{1}{c}{ Variabel Lain } & $\begin{array}{c}\text { Arah } \\
\text { Hubungan }\end{array}$ & Tingkat Hubungan \\
\hline 1. & Motivasi & Positif & Moderat \\
\hline 2. & Keterlibatan dalam pekerjaan & Positif & Moderat \\
\hline 3. & Perilaku Pekerja & Positif & Moderat \\
\hline 4. & Komitmen Organisasi & Positif & Kuat \\
\hline 5. & Kemangkiran & Negatif & Lemah \\
\hline 6. & Keluar-masuknya karyawan & Negatif & Moderat \\
\hline 7. & Stres & Negatif & Kuat \\
\hline 8. & Kinerja & Positif & Lemah \\
\hline
\end{tabular}

Sumber: Kreitner\&Kinicki (2001), (dalam Suparyadi,2017:447)

\section{Motivasi}

Motivasi (motivation) adalah :"sebagai proses yang menjelaskan intensitas, arah, dan ketekunan seseorang individu untuk mencapai tujuannya".(Robbins,2008:222) Intensitas berhubungan dengan seberapa giat seseorang berusaha. Intensitas yang tinggi belum menjamin kinerja karyawan memuaskan jika tidak dikaitkan dengan arah untuk mencapai tujuan yang menguntungkan organisasi.

Menurut Fred Luthans terdiri dari tiga unsur motivasi yakni :'kebutuhan (need), dorongan (drive), dan tujuan (goals). Dorongan ini yang menyebabkan mengapa seseorang itu berusaha mencapai tujuan-tujuan, baik sadar ataupun tidak sadar. Tujuan adalah sesuatu yang ingin dicapai yang berada di luar diri individu misal harapan untuk mendapatkan penghargaan. Orang yang satu berbeda dengan yang lain tergantung pada kemampuannya untuk bekerja juga tergantung pada keinginan mereka untuk bekerja. (kutipan dari penulis dalam penelitiannya terdahulu, 2015). Kesimpulannya orang yang mempunyai motivasi, merasa puas dengan pekerjaannya serta akan berperan memahami pekerjaannya maka akan berusaha mencapai tujuan dan mempunyai komitmen organisasi.

\section{Keterlibatan Kerja.}

Keterlibatan kerja (job involvement) adalah: "Derajat sejauh mana seseorang memihak pada pekerjaannya, berpartisipasi aktif dalamnya, dan menganggap kinerjanya penting bagi harga diri. (Robbins,2006:116). Keterlibatan Karyawan (employee engagement), yaitu keterlibatan, kepuasan, dan antusiasme individual dengan kerja yang mereka lakukan. (Robbins,2008:103). Kesimpulannya bahwa peran serta seseorang dalam 
pekerjaannya karena merasa puas dan termotivasi maka akan mempunyai rasa komitmen dalam organisasi.

\section{Komitmen Organisasi.}

Keterlibatan kerja (job involvement) adalah :'Derajat sejauh mana seseorang memihak pada pekerjaannya, berpartisipasi aktif dalamnya, dan menganggap kinerjanya penting bagi harga diri. (Robbins,2006:116).

\section{METODE PENELITIAN}

Penelitian ini menyajikan Analisis Pengaruh Kepuasan Kerja, Motivasi, Keterlibatan Kerja Terhadap Komitmen Organisasi Pada Karyawan Fakultas Bisnis Dan Akuntansi serta Fakultas Sains dan Teknologi,di Kampus Bangau Universitas Katolik Musi Charitas Palembang. Penelitian ini menggunakan hipotesis dan menggunakan data berdasarkan fakta yang telah dikumpulkan dari hasil jawaban responden karyawan tenaga pendidik dan tenaga pendukung pendidikan pada Fakultas Bisnis Dan Akuntansi, Fakultas Sains danTeknologi, di Universitas Katolik Musi Charitas Palembang. Lokasi penelitian di Jalan Bangau No.60, Palembang.

Jenis Penelitian ini adalah: Studi kasus, tujuannya adalah menganalisis serta menguji data-data dan fakta. Penelitian ini termasuk penelitian kausalitas karena menguji hipotesis "Pengaruh Kepuasan Kerja, Motivasi, Keterlibatan Kerja Terhadap Komitmen Organisasi Pada Karyawan Fakultas Bisnis dan Akuntansi, Fakultas Sains dan Teknologi di Kampus Bangau Unika Musi Charitas".(Ferdinand,2006)

Variabel yang digunakan dalam penelitian ini diukur menggunakan skala likert dengan skala 1-5 (1= sangat tidak setuju sampai dengan $5=$ sangat setuju). Kuesioner yang berupa pernyataan yang harus dipilih salah satu jawaban sebagai teknik pengumpulan datanya.

Kuesioner akan dibagikan langsung kepada responden dengan cara convinience. Sampel yang didapatkan sejumlah 60 orang dan yang memenuhi kelengkapan dalam pengisian kuesioner hanya sejumlah 57 orang.

\section{Teknik Analisis Data dan Pengujian Hipotesis.}

Tahap awal analisis data dilakukan dengan uji validitas dan reliabilitas untuk menguji instrumen, kemudian menyajikan jumlah data dari sampel yang diperoleh, statistik deskriptif dan sampel responden. Langkah ke dua dilakukan uji asumsi klasik agar model regresi yang digunakan tidak bias atau tidak mengandung kesalahan. (Sarwono,2006). Pengujian asumsi klasik diperlukan dalam penelitian ini karena model penelitian yang digunakan adalah regresi. Uji asumsi klasik yang digunakan adalah (1) uji normalitas, bertujuan untuk menguji apakah dalam model regresi, variabel pengganggu atau residual telah memiliki distribusi normal, (2) Uji multikolinearitas bertujuan untuk menguji apakah dalam model regresi ditemukan adanya korelasi antar variabel bebas (independen). Model regresi yang baik seharusnya tidak terjadi korelasi di antara variabel independen. (Usman,2006). Selanjutnya akan dilakukan pengujian hipotesis dengan menggunakan model regresi linier berganda atau metode satu jalur, (Sarwono,2006). 


\section{Hipotesis}

Ada Pengaruh Kepuasan Kerja, Motivasi, Keterlibatan Kerja Terhadap Komitmen Organisasi Pada Karyawan Kampus Bangau Unika Musi Charitas di Palembang. Teknik analisis menggunakan analisis kuantitatif dengan regresi linier berganda dan kualitatif mendeskripsikan hasil olahan data kuantitatif menggunakan SPSS 23. Hasil penelitian diharapkan Kepuasan Kerja, Motivasi, Keterlibatan Kerja Berpengaruh Terhadap Komitmen Organisasi Pada Karyawan Kampus Bangau Unika Musi Charitas di Palembang.

\section{HASIL DAN PEMBAHASAN}

Berdasarkan data yang didapatkan dari jawaban responden tentang karakteristik responden bahwa diperoleh jawaban sebagai berikut :

1. Berdasarkan Gender Responden : Laki-laki sejumlah $=18$ orang dan Perempuan sejumlah $=39$ orang.

2. Berdasarkan fungsionalnya : Dosen dengan tugas tambahan $(D T)=15$ orang., Dosen tanpa tugas tambahan $=22$ orang., Karyawan bukan dosen $=20$ orang

3. Berdasarkan tempat berkarya karyawan : Fakultas Teknik $=14$ orang., Fakultas Bisnis Dan Akuntansi $=33$ orang., Universitas $=10$ orang.

4. Berdasarkan Lama Kerja : 1-5 tahun $=22$ orang., 6-10 tahun $=19$ orang., 11-15 tahun $=4$ orang., $16-20$ tahun $=5$ orang., 21-25 tahun $=7$ orang.

Berdasarkan Uji Validitas dan Uji Reliabilitas yang didapatkan dari olah data kuesioner bahwa variabel-variabel yang diteliti dinyatakan valid dan reliabel. Dinyatakan valid karena angka tingkat signifikan 0,000 lebih kecil dari 0,5. $(0,00<0,5)$ dan dinyatakan reliabel karena angka tingkat Cronbach's Alpha lebih besar dari Cronbach's Alpha yang disyaratkan 0,66 > 0,60.

\section{Berdasarkan Variabel-variabel Frekuensi dari Jawaban Responden}

Berdasarkan hasil jawaban responden bahwa responden menyatakan adanya kepuasan sosial dalam hal persahabatan diantara mereka, yang menjawab sangat setuju sejumlah 14 orang, sedangkan 37 orang menyatakan setuju dan 5 orang menyatakan kurang setuju, tetapi masih ada 1 orang sangat tidak setuju. Kesimpulan : bahwa masih ada yang belum merasakan persahabatan sejumlah 6 orang. Meskipun sebagian besar sejumlah 51 orang sudah merasakan persahabatan (Nilai Integrity).

Berdasarkan hasil jawaban responden bahwa responden menyatakan adanya kepuasan sosial dalam hal jaminan kerja diantara mereka yang menjawab sangat setuju sejumlah 3 orang, sedangkan 36 orang menyatakan setuju dan 14 orang menyatakan kurang setuju, tetapi masih ada 2 orang tidak setuju dan 2 orang sangat tidak setuju. Kesimpulan : bahwa masih ada yang belum merasakan kepuasan dalam hal pemberian jaminan kerja sejumlah 16 orang. Meskipun sebagian besar sejumlah 39 orang sudah merasakan puas akan jaminan kerja yang didapatkan (Nilai Management Capacity)

Berdasarkan hasil jawaban responden bahwa responden menyatakan adanya kepuasan sosial dalam perlakuan yang diterima diantara mereka, yang menjawab sangat setuju sejumlah 12 orang, sedangkan 32 orang menyatakan setuju dan 10 orang menyatakan kurang setuju, tetapi masih ada 2 orang tidak setuju. Kesimpulan : bahwa masih ada yang belum merasakan kepuasan dalam hal perlakuan yang diterima diantara mereka sejumlah 6 orang. Meskipun sebagian besar sejumlah 51 orang sudah merasakan kepuasan dalam hal perlakuan yang diterima diantara mereka (Nilai Humanity) 
Berdasarkan hasil jawaban responden bahwa responden menyatakan adanya kepuasan ekstrinsik dalam hal gaji dan tunjangan, yang menjawab sangat setuju sejumlah 4 orang, sedangkan 35 orang menyatakan setuju dan 11 orang menyatakan kurang setuju, tetapi masih ada 4 orang tidak setuju dan 3 orang menyatakan sangat tidak setuju. Kesimpulan: bahwa masih ada yang belum merasakan kepuasan dalam kepuasan ekstrinsik - gaji dan tunjangan sejumlah 18 orang. Meskipun sebagian besar sejumlah 39 orang sudah merasakan kepuasan dalam hal kepuasan ekstrinsik - gaji dan tunjangan (Nilai Management Capacity).

Berdasarkan hasil jawaban responden bahwa responden menyatakan adanya kepuasan ekstrinsik dalam hal menyelesaikan pekerjaan (Nilai Open Minded), yang menjawab sangat setuju sejumlah 8 orang, sedangkan 45 orang menyatakan setuju dan 2 orang menyatakan kurang setuju, tetapi masih ada 1 orang tidak setuju dan 1 orang menyatakan sangat tidak setuju . Kesimpulan: bahwa masih ada yang belum merasakan kepuasan dalam kepuasan ekstrinsik - dalam menyelesaikan pekerjaan sejumlah 4 orang. Meskipun sebagian besar sejumlah 53 orang sudah merasakan kepuasan dalam hal kepuasan ekstrinsik - dalam kebebasan menyelesaikan pekerjaan (Nilai Open Minded).

Berdasarkan hasil jawaban responden bahwa responden menyatakan adanya kepuasan ekstrinsik dalam hal Kesempatan dapat membantu dalam menyelesaikan pekerjaan orang lain (Nilai Altruism), yang menjawab sangat setuju sejumlah 9 orang, sedangkan 43 orang menyatakan setuju dan 2 orang menyatakan kurang setuju, tetapi masih ada 1 orang tidak setuju dan 1 orang menyatakan sangat tidak setuju . Kesimpulan: bahwa masih ada yang belum merasakan kepuasan dalam kepuasan ekstrinsik - dalam Kesempatan dapat membantu dalam menyelesaikan pekerjaan orang lain sejumlah 4 orang. Meskipun sebagian besar sejumlah 52 orang sudah merasakan kepuasan dalam hal kepuasan ekstrinsik - dalam Kesempatan dapat membantu dalam menyelesaikan pekerjaan orang lain (Nilai Altruism).

Berdasarkan hasil jawaban bahwa responden menyatakan adanya Kepuasan Intrinsik - Kesempatan Belajar hal-hal yang baru. (Nilai Novelty), yang menjawab sangat setuju sejumlah 10 orang, sedangkan 41 orang menyatakan setuju dan 4 orang menyatakan kurang setuju, tetapi masih ada 1 orang tidak setuju dan 1 orang menyatakan sangat tidak setuju . Kesimpulan : bahwa masih ada yang belum merasakan kepuasan dalam Kepuasan Intrinsik - Kesempatan Belajar hal-hal yang baru (Nilai Novelty) sejumlah 6 orang. Meskipun sebagian besar sejumlah 51 orang sudah merasakan kepuasan dalam hal tersebut

Berdasarkan hasil jawaban bahwa responden menyatakan adanya Kepuasan Intrinsik - Melakukan hal-hal yang berharga atau penting (Nilai Persistence) yang menjawab sangat setuju sejumlah 7 orang, sedangkan 39 orang menyatakan setuju dan 9 orang menyatakan kurang setuju, tetapi masih ada 2 orang tidak setuju. Kesimpulan : bahwa masih ada yang belum merasakan kepuasan dalam Kepuasan Intrinsik Kesempatan melakukan hal-hal yang berharga atau penting (Nilai Persistence) sejumlah 11 orang. Meskipun sebagian besar sejumlah 46 orang sudah merasakan kepuasan dalam hal tersebut.

Berdasarkan hasil jawaban responden bahwa responden menyatakan adanya Kepuasan Intrinsik - Ikut membuat keputusan (Management Capacity), yang menjawab sangat setuju sejumlah 9 orang, sedangkan 38 orang menyatakan setuju dan 6 orang menyatakan kurang setuju, tetapi masih ada 3 orang tidak setuju. dan 1 orang menjawab sangat tidak setuju. Kesimpulan : bahwa masih ada yang belum merasakan kepuasan dalam Kepuasan Intrinsik - Kesempatan Ikut membuat keputusan (Management 
Capacity) sejumlah 11 orang. Meskipun sebagian besar sejumlah 47 orang sudah merasakan kepuasan dalam hal tersebut.

\section{Variabel-variabel Motivasi}

Berdasarkan hasil jawaban responden bahwa responden menyatakan adanya motivasi kebutuhan berprestasi dalam hal - Menerima tantangan yang sulit, yang menjawab sangat setuju sejumlah 7 orang, sedangkan 39 orang menyatakan setuju dan 9 orang menyatakan kurang setuju, tetapi masih ada 2 orang tidak setuju. Kesimpulan : bahwa masih ada yang belum merasakan adanya motivasi kebutuhan berprestasi dalam hal - Menerima tantangan yang sulit (Nilai Open Minded). sejumlah 11 orang. Meskipun sebagian besar sejumlah 46 orang sudah merasakan / menikmati adanya motivasi kebutuhan berprestasi dalam hal - menerima tantangan yang sulit.

Berdasarkan hasil jawaban responden bahwa responden menyatakan adanya motivasi kebutuhan berprestasi dalam hal - Menetapkan Tujuan \& Mencapai Tujuan yang realistis,(Nilai Integrity) yang menjawab sangat setuju sejumlah 7 orang, sedangkan 43 orang menyatakan setuju dan 6 orang menyatakan kurang setuju, tetapi masih ada 1 orang tidak setuju. Kesimpulan : bahwa masih ada yang belum merasakan adanya motivasi kebutuhan berprestasi dalam hal - Menetapkan tujuan \& mencapai tujuan yang realistis, sejumlah 7 orang. Meskipun sebagian besar sejumlah 50 orang sudah merasakan / menikmati adanya motivasi kebutuhan berprestasi dalam hal Menetapkan Tujuan \& Mencapai Tujuan yang realistis (Nilai Integrity).

Berdasarkan hasil jawaban responden bahwa responden menyatakan adanya motivasi kebutuhan berprestasi dalam hal - Kemajuan yang dicapai dalam menyelesaikan tugas, (Nilai Open Minded) yang menjawab sangat setuju sejumlah 14 orang, sedangkan 37 orang menyatakan setuju dan 5 orang menyatakan kurang setuju, tetapi masih ada 1 orang tidak setuju. Kesimpulan : bahwa masih ada yang belum merasakan adanya motivasi kebutuhan berprestasi dalam hal - Kemajuan yang dicapai dalam menyelesaikan tugas ,sejumlah 6 orang. Meskipun sebagian besar sejumlah 51 orang sudah merasakan / menikmati adanya motivasi kebutuhan berprestasi dalam hal - Kemajuan yang dicapai dalam menyelesaikan tugas, (Nilai Open Minded).

Berdasarkan hasil jawaban responden bahwa responden menyatakan adanya motivasi kebutuhan Kekuasaan-Tanggung Jawab dalam melaksanakan pekerjaan. (Nilai Open Minded), yang menjawab sangat setuju sejumlah 3 orang, sedangkan 36 orang menyatakan setuju dan 14 orang menyatakan kurang setuju, tetapi masih ada 2 orang tidak setuju, serta 2 orang menyatakan sangat tidak setuju. Kesimpulan : bahwa masih ada yang belum merasakan adanya motivasi kekuasaan - tanggung Jawab dalam melaksanakan pekerjaan sejumlah 18 orang. Meskipun sebagian besar sejumlah 39 orang sudah merasakan / menikmati adanya motivasi kebutuhan kekuasaan - Tanggung Jawab dalam melaksanakan pekerjaan. (Nilai Open Minded)

Berdasarkan hasil jawaban responden bahwa responden menyatakan adanya motivasi kebutuhan Kekuasaan - Suka mempengaruhi orang lain untuk mengikuti caranya (Nilai Open Minded), yang menjawab sangat setuju sejumla 6 orang, sedangkan 39 orang menyatakan setuju dan 9 orang menyatakan kurang setuju, tetapi masih ada 3 orang tidak setuju. Kesimpulan : bahwa masih ada yang belum merasakan adanya motivasi Kekuasaan - Tanggung Jawab dalam Suka mempengaruhi orang lain untuk mengikuti caranya sejumlah 12 orang. Meskipun sebagian besar sejumlah 45 orang sudah merasakan / menikmati adanya motivasi kebutuhan Kekuasaan - Suka mempengaruhi orang lain untuk mengikuti caranya. (Nilai Open Minded). 
Berdasarkan hasil jawaban bahwa responden menyatakan adanya motivasi kebutuhan Kekuasaan - Menyampaikan Langsung kepada orang yang menyatakan sesuatu yang tidak disetujui, (Nilai Open Minded) yang menjawab sangat setuju sejumlah 4 orang, sedangkan 37 orang menyatakan setuju dan 10 orang menyatakan kurang setuju, tetapi masih ada 3 orang tidak setuju, dan 3 orang sangat tidak setuju. Kesimpulan bahwa masih ada yang belum merasakan adanya motivasi Kekuasaan -Menyampaikan Langsung kepada orang yang menyatakan sesuatu yang tidak disetujui sejumlah 16 orang. Meskipun sebagian besar sejumlah 41 orang sudah merasakan/menikmati adanya motivasi kebutuhan Kekuasaan - Menyampaikan langsung kepada orang yang menyatakan sesuatu yang tidak disetujui.

Berdasarkan hasil jawaban responden bahwa responden menyatakan adanya motivasi kebutuhan Kekuasaan - Membantu dalam membicarakan masalah diluar pekerjaan (Nilai Charity) yang menjawab sangat setuju sejumlah 9 orang, sedangkan 45 orang menyatakan setuju dan 2 orang menyatakan kurang setuju, tetapi masih ada 1 orang sangat tidak setuju. Kesimpulan : bahwa masih ada yang belum merasakan adanya motivasi Kekuasaan - Membantu dalam hal membicarakan masalah diluar pekerjaan sejumlah 3 orang. Meskipun sebagian besar sejumlah 54 orang sudah merasakan atau menikmati adanya motivasi kebutuhan Kekuasaan - Membantu dalam hal membicarakan masalah diluar pekerjaan (Nilai Charity).

Berdasarkan hasil jawaban responden bahwa responden menyatakan adanya Motivasi Kebutuhan Afiliasi - Menikmati bagian dari kelompok organisasi. (Nilai Humanity), yang menjawab sangat setuju sejumlah 12 orang, sedangkan 41 orang menyatakan setuju dan 2 orang menyatakan kurang setuju, tetapi masih ada 1 orang tidak setuju dan 1 orang sangat tidak setuju. Kesimpulan : bahwa masih ada yang belum merasakan adanya motivasi Kekuasaan - Kebutuhan Afiliasi - Menikmati bagian dari kelompok organisasi sejumlah 4 orang. Meskipun sebagian besar sejumlah 53 orang sudah merasakan/menikmati adanya Kebutuhan Afiliasi - Menikmati bagian dari kelompok organisasi. (Nilai Humanity).

Berdasarkan hasil jawaban responden bahwa responden menyatakan adanya Motivasi Kebutuhan Afiliasi - Menikmati bekerja sama dengan orang lain daripada bekerja sendiri. (Nilai Altruism), yang menjawab sangat setuju sejumlah 14 orang, sedangkan 37 orang menyatakan setuju dan 2 orang menyatakan kurang setuju, tetapi masih ada 4 orang kurang setuju, 1 orang tidak setuju dan 1 orang sangat tidak setuju. Kesimpulan : bahwa masih ada yang belum merasakan adanya Motivasi Kekuasaan Kebutuhan Afiliasi - Menikmati bekerja sama dengan orang lain daripada bekerja sendiri. (Nilai Altruism) sejumlah 6 orang. Meskipun sebagian besar sejumlah 51 orang sudah merasakan/menikmati adanya kebutuhan Afiliasi - Menikmati bekerja sama dengan orang lain daripada bekerja sendiri. (Nilai Altruism).

\section{Variabel-variabel Keterlibatan Kerja}

Berdasarkan hasil jawaban responden bahwa responden menyatakan adanya Keterlibatan Kerja - Ketertarikan dengan pekerjaannya (Nilai Open Minded), yang menjawab sangat setuju sejumlah 7 orang, sedangkan 44 orang menyatakan setuju dan 5 orang menyatakan kurang setuju, 1 orang sangat tidak setuju. Kesimpulan : bahwa masih ada yang belum merasakan adanya Keterlibatan Kerja Ketertarikan dengan Pekerjaannya (Nilai Open Minded), sejumlah 6 orang. Meskipun sebagian besar sejumlah 51 orang sudah merasakan atau menikmati adanya Keterlibatan Kerja - Ketertarikan dengan pekerjaannya (Nilai Open Minded). 
Berdasarkan hasil jawaban responden bahwa responden menyatakan adanya Keterlibatan Kerja - Pekerjaan yang memiliki arti tidak hanya sekedar uang. (Nilai Persistance) yang menjawab sangat setuju sejumlah 5 orang, sedangkan 38 orang menyatakan setuju dan 9 orang menyatakan kurang setuju, 4 orang tidak setuju dan 1 orang sangat tidak setuju. Kesimpulan : bahwa masih ada yang belum merasakan adanya Keterlibatan Kerja Pekerjaan yang memiliki arti tidak hanya sekedar uang. (Nilai Persistance), sejumlah 14 orang. Meskipun sebagian besar sejumlah 43 orang sudah merasakan/menikmati adanya Keterlibatan Kerja - Pekerjaan yang memiliki arti tidak hanya sekedar uang (Nilai Persistance).

Berdasarkan hasil jawaban responden bahwa responden menyatakan adanya Keterlibatan Kerja - Selalu Membuat Rencana untuk pekerjaannya. (Nilai Persistance), yang menjawab sangat setuju sejumlah 8 orang, sedangka 40 orang menyatakan setuju dan 7 orang menyatakan kurang setuju, 2 orang tidak setuju. Kesimpulan : bahwa masih ada yang belum merasakan adanya selalu Membuat Rencana untuk pekerjaannnya, sejumlah 9 orang. Meskipun sebagian besar sejumlah 48 orang sudah merasakan selalu membuat rencana untuk pekerjaannya. (Nilai Persistance).

Berdasarkan hasil jawaban responden bahwa responden menyatakan adanya Keterlibatan Kerja - Bersedia Kerja Lembur (Nilai Persistance), yang menjawab sangat setuju sejumlah 10 orang, sedangkan 44 orang menyatakan setuju dan 3 orang menyatakan kurang setuju. Kesimpulan : bahwa masih ada yang belum merasakan adanya bersedia kerja lembur, sejumlah 3 orang. Meskipun sebagian besar sejumlah 54 orang sudah merasakan bersedia kerja lembur (Nilai Persistance).

\section{Variabel-variabel Komitmen Organisasional}

Berdasarkan hasil jawaban responden bahwa responden menyatakan adanya Komitmen Organisasi - Merasa Senang Menghabiskan Waktu Karir di Organisasi ini (Nilai Open Minded) - yang menjawab sangat setuju sejumlah 16 orang, sedangkan 40 orang menyatakan setuju dan 1 orang menyatakan kurang setuju. Kesimpulan : bahwa masih ada yang belum merasakan adanya Merasa Senang Menghabiskan Waktu Karir di Organisasi ini, sejumlah 1 orang. Meskipun sebagian besar sejumlah 56 orang sudah merasakan Merasa Senang Menghabiskan Waktu Karir di Organisasi ini, (Nilai Open Minded).

Berdasarkan hasil jawaban responden bahwa responden menyatakan adanya Komitmen Organisasi - Merasa Masalah Organisasi juga menjadi masalahnya (Nilai Altruism) yang menjawabsangat setuju sejumlah 13 orang, sedangkan 41 orang menyatakan setuju dan 3 orang menyatakan kurang setuju. Kesimpulan : bahwa masih ada yang belum merasakan adanya Merasa Masalah Organisasi juga menjadi masalahnya (Nilai Altruism), sejumlah 3orang. Meskipun sebagian besar sejumlah 54 orang sudah merasakan -Masalah Organisasi juga menjadi masalahnya.

Berdasarkan hasil jawaban responden bahwa responden menyatakan adanya Komitmen Organisasi - Nilai-nilai yang diinginkan individu sama dengan nilai-nilai yang diinginkan organisasasi yang menjawabsangat setuju sejumlah 3 orang, sedangkan 21 orang menyatakan setuju dan 22 orang menyatakan kurang setuju, 4 orang menyatakan tidak setuju, dan 7 orang menyatakan sangat tidak setuju. Kesimpulan : bahwa masih ada yang belum merasakan adanya Nilai-nilai yang diinginkan individu sama dengan nilai-nilai yang diinginkan organisasasi (Nilai Champion), sejumlah 33 orang. Meskipun sebagian besar sejumlah 24 orang sudah merasakan Nilai-nilai yang diinginkan individu sama dengan nilai-nilai yang diinginkan organisasi. 
Berdasarkan hasil jawaban responden bahwa responden menyatakan adanya Komitmen Organisasi - Bangga menjadi bagian dari organisasi, yang menjawab sangat setuju sejumlah 7 orang, sedangkan 34 orang menyatakan setuju dan 11 orang menyatakan kurang setuju, 1 orang menyatakan tidak setuju, dan 4 orang menyatakan sangat tidak setuju. Kesimpulan : bahwa masih ada yang belum merasakan adanya bangga menjadi bagian dari organisasi. sejumlah 16 orang. Meskipun sebagian besar sejumlah 41 orang sudah merasakan hal tersebut, (Nilai Altruism)

\section{Uji Asumsi Klasik}

\section{Tabel Hasil Uji Multikolinier}

Berdasarkan tabel tersebut diatas menunjukkan bahwa nilai VIF variabel kepuasan kerja (X1), variabel motivasi kerja (X2), variabel keterlibatan kerja (X3), ketiga variabel tersebut nilai VIF $<10$ dan memiliki nilai tolerance $>0,1$., Maka pada model regresi ini tidak terjadi multikolinier.

\section{Tabel Hasil Uji Heterokedastisitas}

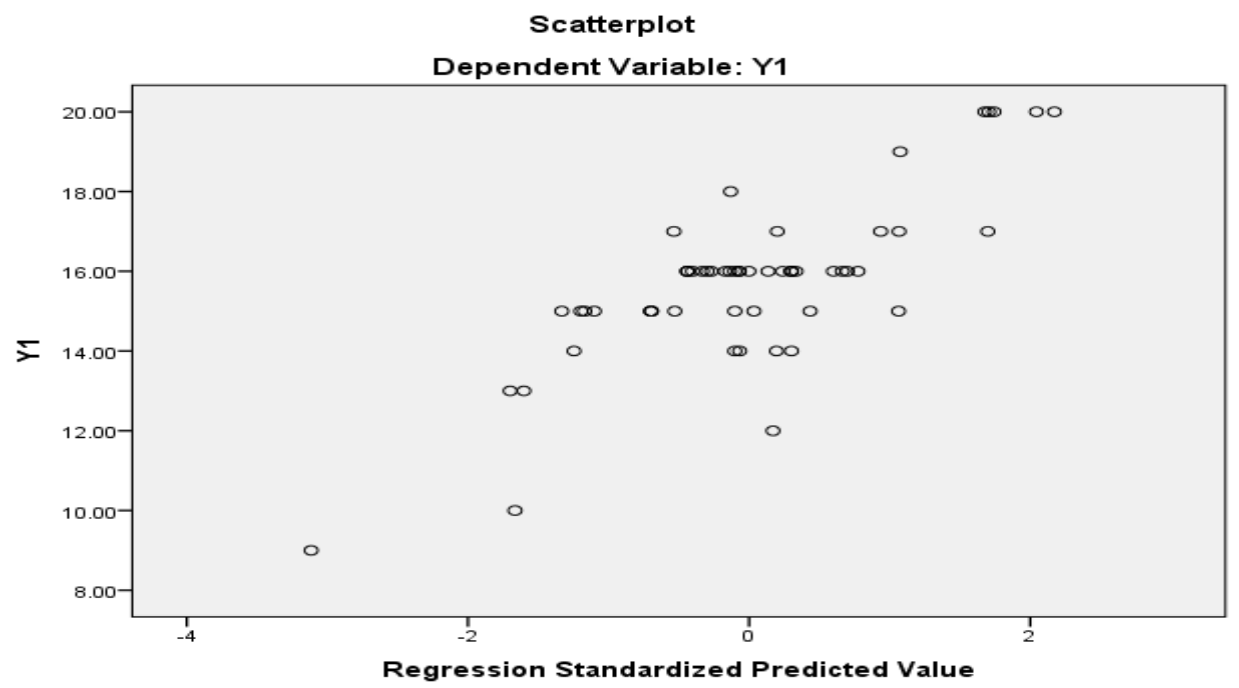

Berdasarkan grafik tersebut diatas menunjukkan bahwa titik-titik yang menyebar secara acak dibawah dan diatas angka 0 pada sumbu Y. Hal tersebut menyatakan tidak terjadinya heterokedastisitas pada model regresi, sehingga layak digunakan untuk memprediksi variabel komitmen organisasi.

\section{Tabel Hasil Uji Normalitas}

Normal P-P Plot of Regression Standardized Residual

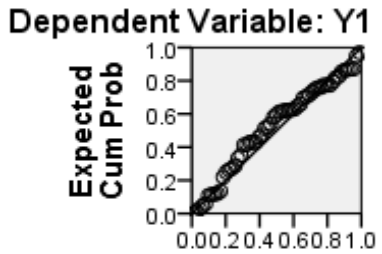

Observe

d Cum .. 
Berdasarkan grafik tersebut diatas menunjukkan bahwa titik-titik yang menyebar disekitar mengikuti arah garis diagonal, maka data yang digunakan memenuhi asumsi normalitas, sehingga dapat dilanjutkan ke regresi.

\section{Analisis Data Regresi.}

Teknik analisis yang digunakan uji regresi, dimana variabel $\mathrm{X}$ terdiri dari 3 (tiga) variabel dengan sejumlah 22 (dua puluh dua) indikator dan variabel Y hanya 1 (satu) variabel dengan sejumlah 4 (empat) indikator, olah data menggunakan SPSS (Sarwono, Puspowarsito, Imam Ghozali)

\section{Analisis Regresi}

Dengan melihat perhitungan pengaruh secara gabungan variabel kepuasan kerja, motivasi dan keterlibatan kerja terhadap komitmen organisasi dapat dilihat dari hasil perhitungan dalam model summary, khususnya angka R Square dibawah ini. Untuk menghitung Koefisien Determinan (KD) menggunakan rumus sebagai berikut: $K D=r^{2} x$ $100 \%$. Sedangkan untuk mengetahui apakah model regresi diatas sudah benar maka diperlukan uji hipotesis. Hipotesisnya sebagai berikut :

HO : Tidak ada hubungan linier antara variabel kepuasan kerja, motivasi dan keterlibatan kerja terhadap komitmen organisasi

H1 : Ada hubungan linier antara variabel kepuasan kerja, motivasi dan keterlibatan kerja terhadap komitmen organisasi

Uji Hipotesis menggunakan angka signifikan dengan kriteria sebagai berikut :

1. Jika angka signifikan >0,05 maka H0 diterima dan H1 ditolak, artinya tidak ada hubungan antara variabel $\mathrm{X}$ dengan variabel $\mathrm{Y}$.

2. Jika angka signifikan $<0,05$ maka H0 ditolak dan $\mathrm{H} 1$ diterima, artinya ada hubungan antara variabel $\mathrm{X}$ dengan variabel $\mathrm{Y}$.

\section{Perhitungan Regresi Dan Hipotesis Antara Variabel X1, X2, X3 Terhadap Variabel Y1.1 (Variabel Kepuasan Kerja, Motivasi Dan Keterlibatan Kerja Terhadap Komitmen Organisasi)}

Tabel Hasil Uji F.

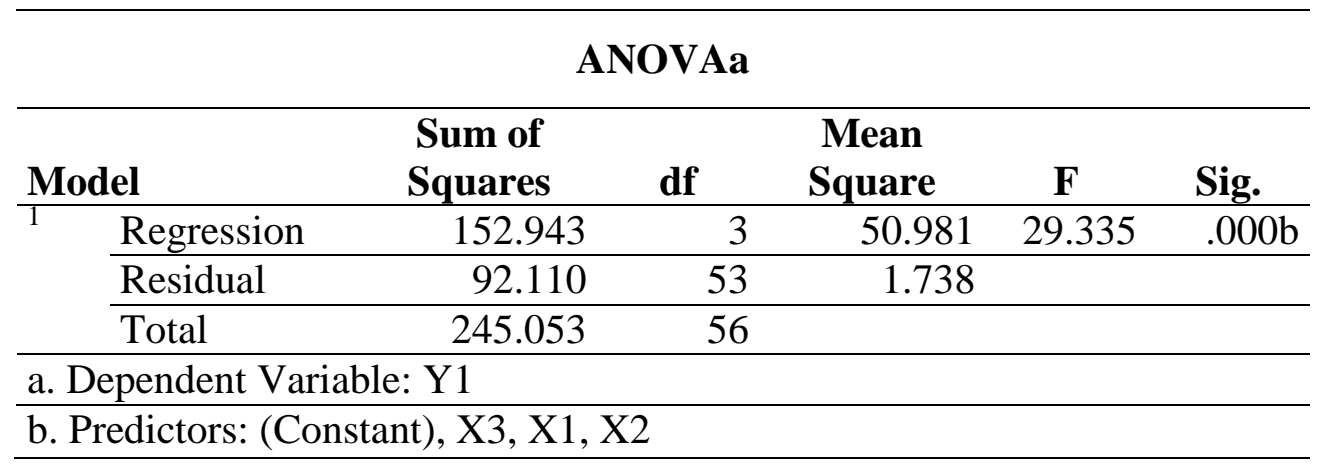

Berdasarkan tabel tersebut diatas menunjukkan bahwa nilai $\mathrm{F}$ hitung sebesar 29.335 dengan signifikan $0,000<0,05$ maka dinyatakan variabel kepuasan kerja, motivasi dan keterlibatan kerja secara bersama-sama memiliki pengaruh yang signifikan terhadap komitmen organisasi. 
Tabel Hasil Uji t

\begin{tabular}{|c|c|c|c|c|c|c|c|c|}
\hline \multicolumn{9}{|c|}{ Coefficients $^{\mathrm{a}}$} \\
\hline \multirow[b]{2}{*}{ Mode } & & \multicolumn{2}{|c|}{$\begin{array}{c}\text { Unstandardized } \\
\text { Coefficients } \\
\end{array}$} & \multirow{2}{*}{$\begin{array}{c}\begin{array}{c}\text { Standardized } \\
\text { Coefficients }\end{array} \\
\text { Beta }\end{array}$} & \multirow[b]{2}{*}{$\mathbf{t}$} & \multirow[b]{2}{*}{ Sig. } & \multicolumn{2}{|c|}{$\begin{array}{c}\text { Collinearity } \\
\text { Statistics } \\
\end{array}$} \\
\hline & & B & $\begin{array}{c}\text { Std. } \\
\text { Error }\end{array}$ & & & & Tolerance & VIF \\
\hline 1 & (Constant) & -1.444 & 1.998 & & -.723 & .473 & & \\
\hline & $\mathrm{X} 1$ & .274 & .040 & .617 & 6.877 & .000 & .880 & 1.137 \\
\hline & $\mathrm{X} 2$ & .167 & .055 & .315 & 3.032 & .004 & .656 & 1.524 \\
\hline & $\mathrm{X} 3$ & .112 & .135 & .091 & .830 & .410 & .594 & 1.683 \\
\hline
\end{tabular}

1. Nilai t hitung untuk variabel $X 1$ sebesar 6,877 dengan signifikan $0,000<0,05$ maka dinyatakan $\mathrm{H} 0$ ditolak dan $\mathrm{H} 1$ diterima berarti variabel kepuasan kerja (X1), berpengaruh secara signifikan terhadap variabel komitmen organisasi (Y).

2. Nilai t hitung untuk variabel $\mathrm{X} 2$ sebesar 3,032 dengan signifikan $0,004<0,05$ maka dinyatakan $\mathrm{H} 0$ ditolak dan $\mathrm{H} 1$ diterima berarti variabel motivasi kerja (X2), berpengaruh secara signifikan terhadap variabel komitmen organisasi (Y).

3. Nilai t hitung untuk variabel X3 sebesar 0,830 dengan signifikan 0,410>0,05 maka dinyatakan $\mathrm{H} 0$ diterima dan $\mathrm{H} 1$ ditolak berarti variabel keterlibatan kerja (X3), tidak berpengaruh secara signifikan terhadap variabel komitmen organisasi (Y).

4. Berdasarkan tabel teersebut diatas dapat menunjukkan persamaan regresi linier sebagai berikut :

$\mathrm{Y}=-1,444+0,274 \mathrm{X} 1+0,167 \mathrm{X} 2+0,112 \mathrm{X} 3$

Dari persamaan tersebut diatas menunjukkan bahwa :

a. Nilai konstanta sebesar - 1,444 mempunyai arti bahwa jika variabel kepuasan kerja, motivasi kerja, keterlibatan kerja secara bersama-sama tidak mengalami perubahan atau sama dengan nol maka besarnya komitmen karyawan -1,444.

b. Koefisien regresi kepuasan kerja sebesar 0,274 berarti variabel kepuasan kerja (X1) mempunyai pengaruh positif terhadap komitmen organisasi.

c. Koefisien regresi motivasi kerja sebesar 0,167 berarti variabel motivasi kerja (X2) mempunyai pengaruh positif terhadap komitmen organisasi.

d. Koefisien regresi keterlibatan kerja sebesar 0,112 berarti variabel keterlibatan kerja (X3) mempunyai pengaruh positif terhadap komitmen organisasi. 
Hasil Analisis Korelasi Regresi Berganda (R) dan koefisien determinant $\left(\mathbf{R}^{\mathbf{2}}\right)$

\begin{tabular}{|c|c|c|c|c|c|c|c|c|c|c|}
\hline \multicolumn{11}{|c|}{ Dependent Variable: Y1 ${ }^{\text {b }}$} \\
\hline \multirow[b]{2}{*}{ Model } & \multirow[b]{2}{*}{$\mathbf{R}$} & \multirow[b]{2}{*}{$\begin{array}{c}\mathbf{R} \\
\text { Square }\end{array}$} & \multirow[b]{2}{*}{$\begin{array}{l}\text { Adjusted } \\
\text { R } \\
\text { Square }\end{array}$} & \multirow{2}{*}{$\begin{array}{c}\text { Std. } \\
\text { Error of } \\
\text { the } \\
\text { Estimate }\end{array}$} & \multicolumn{5}{|c|}{ Change Statistics } & \multirow[b]{2}{*}{$\begin{array}{l}\text { Durbin- } \\
\text { Watson }\end{array}$} \\
\hline & & & & & $\begin{array}{c}\mathbf{R} \\
\text { Square } \\
\text { Change }\end{array}$ & $\begin{array}{c}\text { F } \\
\text { Change }\end{array}$ & df1 & df2 & $\begin{array}{c}\text { Sig. F } \\
\text { Change }\end{array}$ & \\
\hline 1 & $.790^{\mathrm{a}}$ & .624 & .603 & 1.31830 & .624 & 29.335 & 3 & 53 & .000 & 2.218 \\
\hline \multicolumn{11}{|c|}{ a. Predictors: (Constant), X3, X1, X2 } \\
\hline
\end{tabular}

Berdasarkan tabel tersebut diatas menunjukkan bahwa hasil koefisien korelasi determinan R Square sebesar 0,624, mempunyai arti variabel komitmen organisasi dapat dijelaskan (dipengaruhi) oleh variabel X1 (kepuasan kerja), X2 (Motivasi kerja) dan X3 (Keterlibatan kerja) sebesar 0,624 x 100\% $=62,4 \%$, sedangkan sisanya sebesar 37,6\% dipengaruhi oleh variabel faktor lainnya diluar model penelitian.

\section{Pembahasan}

Berdasarkan hasil olah data tersebut diatas jika diperhatikan kembali dengan hasil penelitian terdahulu, bahwa penelitian ini mempunyai kesamaan adanya pengaruh antara variable X (variabel kepuasan kerja, motivasi kerja, keterlibatan kerja) dan variabel $\mathrm{Y}$ (variabel komitmen organisasi). Meskipun ada perbedaan angka atau nilai dalam hal besarnya pengaruh dan signifikannya dengan hasil penelitian terdahulu.

\section{KESIMPULAN DAN IMPLIKASI}

\section{Simpulan}

Berdasarkan hasil analisis pembahasan maka dapat diambil kesimpulan sebagai berikut :

1. Berdasarkan hasil jawaban frekuensi responden menunjukkan sebagian besar responden telah merasakan nilai-nilai champion. Sedangkan yang belum merasakan hanya sekitar antara 1 orang sampai 10 orang responden.

2. Berdasarkan hasil pengujian regresi dan korelasi berganda menunjukkan adanya pengaruh yang signifikan terhadap komitmen organisasi, untuk variabel X1 (kepuasan kerja) dan variabel X2 (motivasi kerja). Sedangkan variabel X3 (keterlibatan kerja) berpengaruh terhadap komitmen organisasi tetapi tidak signifikan.

\section{Saran}

Berdasarkan pembahasan dan temuan-temuan disaat penyebaran kuesioner dan hasil olah data bahwa :

1. Perlu adanya perhatian yang lebih terhadap nilai-nilai champion yang memang sudah ada meskipun tidak atau belum dideskripsikan sebelumnya sebagai nilai-nilai champion di organisasi ini. Nilai-nilai champion bisa terlihat pada setiap indikator pernyataan yang diajukan. Ada beberapa responden yang menjawab peerlu adanya integritas lebih ditingkatkan.

2. Perlu melakukan penelitian dengan melihat variabel lainnya yang dapat dikaitkan dengan komitmen organisasi. 
3. Penelitian ini untuk waktu yang akan datang akan dilaksanakan ke seluruh karyawan universitas katolik musi charitas tidak hanya dikampus bangau, melainkan juga di kampus burlian (fakultas ilmu kesehatan).

\section{Keterbatasan Penelitian}

Keterbatasan dalam penelitian ini selain waktu, tenaga, kesibukan dari masing-masing anggota organisasi (termasuk tim peneliti), sehingga jawaban atau pengisian kuesioner ada yang kurang lengkap dan lama untuk terkumpulnya jawaban responden ini.

\section{Implikasi Penelitian}

Hasil penelitian ini dapat diimplikasikan bagi perguruan tinggi, guna memperbaiki kebijakan-kebijakan, maupun suasana akademis yang berkaitan dengan nilai-nilai champion, dan yang telah ada tetap dipertahankan bahkan dapat ditingkatkan.

\section{DAFTAR PUSTAKA}

H.M.Thamrin.,2012., The Influence of Transformational Leadership and Organizational Commitment On Job Satisfaction and Employe Performance, Internasional Journal of Innovation, Management and Technology,Vol.3,No.5,October, DOI:10.7763/ijimt.2012.V3.299.

Imam Wahjono,Sentot, 2015, Manajemen Sumber Daya Manusia, Salemba Empat, Jakarta.

Koesmono T, 2007, Pengaruh Kepemimpinan dan Tuntutan Tugas Terhadap Komitmen Organisasi dengan Variabel Moderasi Motivasi Perawat Rumah Sakit Swasta Surabaya, Jurnal Manajemen dan Kewirausahaan, Vol.9, No.1, Maret, Universitas Kristen Petra, Surabaya.

Melina Taurisa, Intan Ratnawati., 2012,Analisis Pengaruh Budaya Organisasi Dan Kepuasan organisasional Dalam Meningkatkan Kinerja Karyawan

Muogbo U.S.,2013., The Impact of Employee Motivation On Organizational Performance (Astudy Of Some Selected Firms In Anambra State Nigeria), The International Journal Of Engineering And Science, (IJES), Vol.2, Issue 7, Pages 70 -80, ISSN(E):2319-1813 ISSN(P):2319-1805.

Puspowarsito., 2008, Metode Penelitian Organisasi Dengan Aplikasi Program SPSS, Humaniora, cetakan ke 3, Bandu

Sarwono, Jonathan, 2009, Analisis Data Penelitian Menggunakan SPSS, Andi, Yogyakarta.

Suparyadi,2017, Manajemen Sumber Daya Manusia Mencapai Keunggulan Bersaing Berbasis Kompetensi SDM, Andi, Yogyakarta. 